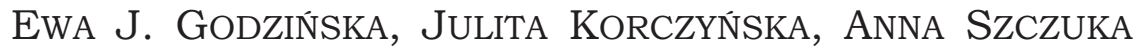

\section{Pracownia Etologii}

Instytut Biologii Doświadczalnej im. M. Nenckiego PAN

Pasteura 3, 02-093 Warszawa

E-mail: e.godzinska@nencki.edu.pl

\section{BOGDAN SADOWSKI (1932-2021): UCZONY, ERUDYTA, NAUCZYCIEL KILKU POKOLEŃ POLSKICH NEUROBIOLOGÓW I BADACZY ZACHOWANIA}

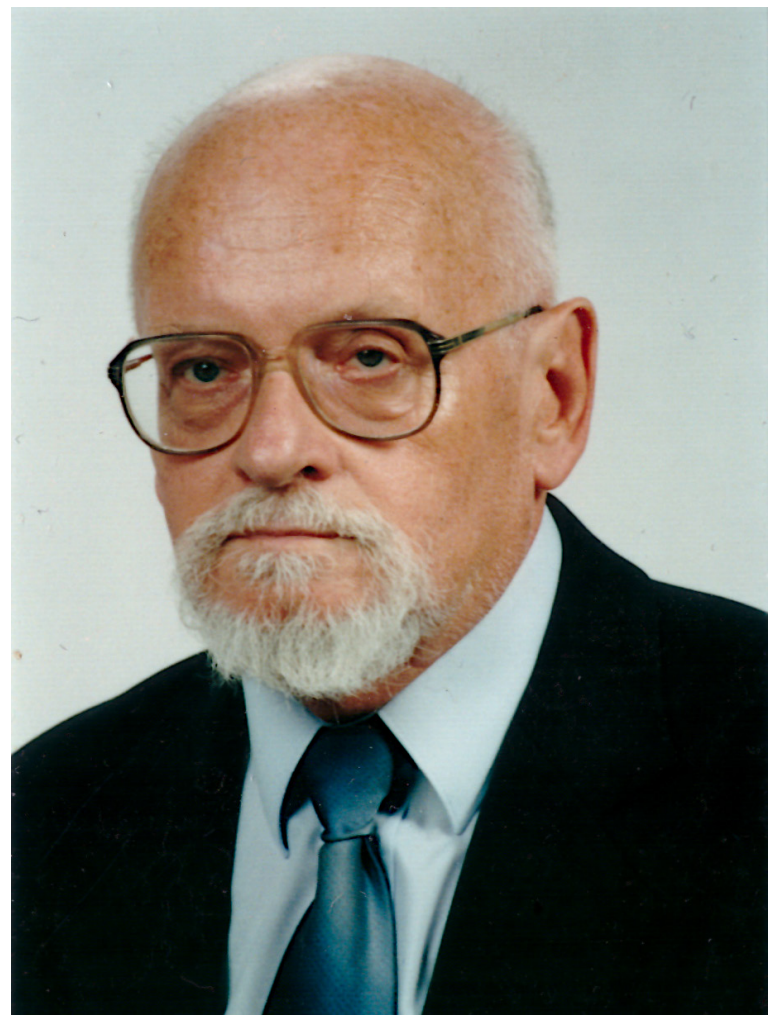

Bogdan Sadowski (1932-2021)

Profesor Bogdan Sadowski (1932-2021) był wybitnym polskim neurobiologiem, badaczem biologicznych mechanizmów zachowania i autorytetem $w$ dziedzinie badań mózgu. Przez wiele lat pracował w Centrum Medycyny Doświadczalnej i Klinicznej PAN w Warszawie. Następnie kierował Zakładem Zachowania się Zwierząt w Instytucie Gene- tyki i Hodowli Zwierzat PAN w Jastrzębcu, a w ostatnich dwóch dekadach życia pracował jako wykładowca w Wyższej Szkole Inżynierii i Zdrowia w Warszawie. Badal szerokie spektrum neurobiologicznych, neurofarmakologicznych i genetycznych uwarunkowań przyczynowych różnorodnych fizjologicznych i behawioralnych zjawisk i procesów obserwowanych u różnych gatunków zwierzat, w tym zwłaszcza u myszy, królików i psów. W szczególności, badał układ nagrody mózgu i rolę układu opioidowego $\mathrm{w}$ analgezji indukowanej przez stres. Był też szeroko znany jako autor i/lub współautor cenionych polskich podręczników akademickich, przekazujacych aktualny stan wiedzy o fizjologicznych, neurobiologicznych i etologicznych mechanizmach zjawisk $i$ procesów behawioralnych u zwierzat i ludzi. Straciliśmy w Nim wybitnego badacza, uczonego i nauczyciela wielu pokoleń neurobiologów i przedstawicieli nauk behawioralnych.

\section{Bogdan Sadowski (1932-2021)}

Professor Bogdan Sadowski (1932-2021) was an eminent Polish neurobiologist, behavioural scientist and an authority in the field of brain research. For many years he worked at the Medical Research Centre PAS in Warsaw. He then acted as the head of the Department of Animal Behaviour at the Institute of Genetics and Animal Breeding PAS in Jastrzębiec, and during the last two decades of his life he was a lecturer at the University of Engineering and Health in Warsaw. He investigated a wide spectrum of neurobiological, neuropharmacological

*Praca nad tą publikacją była finansowana z subwencji Ministerstwa Nauki i Szkolnictwa Wyższego dla Instytutu Biologii Doświadczalnej im. M. Nenckiego PAN 
and genetic causal factors underlying various physiological and behavioural phenomena and processes observed in a wide range of animal species (mostly mice, rabbits and dogs). In particular, he investigated the reward system of the brain and the role of the opioid system in stress-induced analgesia. He was also widely known as the author and/or coauthor of very much appre- ciated Polish academic handbooks spreading current knowledge on physiological, neurobiological and ethological mechanisms underlying behavioral phenomena and processes in animals and humans. We lost an eminent researcher, scholar and teacher of many generations of neurobiologists and behavioral scientists.
W dniu 19 lutego 2021 r. w wieku 89 lat odszedł od nas prof. dr hab. Bogdan Sadowski, neurobiolog, badacz fizjologicznych i biologicznych mechanizmów zachowania, niezapomniany nauczyciel wielu pokoleń polskich neurofizjologów i przedstawicieli nauk behawioralnych. Do ostatnich chwil życia był dla swoich kolegów, współpracowników i studentów źródłem inspiracji i naukowym autorytetem.

Bogdan Sadowski urodził się 15 stycznia 1932 r. w Warszawie. Od wczesnego dzieciństwa wykazywał wszechstronne zainteresowania zdobywaniem wiedzy, zarówno w zakresie nauk przyrodniczych, jak i humanistycznych. Przez całe życie bardzo chętnie uczył się języków. Udało mu się biegle poznać angielski, niemiecki, francuski, rosyjski, włoski, łacinę i grekę, a czytać mógł również $\mathrm{w}$ języku hiszpańskim i węgierskim. W wolnych chwilach czytał dla przyjemności w oryginale Ksenofonta, Plutarcha, Cycerona, Horacego i Tacyta. Jednocześnie odznaczał się dużym poczuciem humoru, a w szkole wyróżniał się skłonnościa do inicjowania swawolnych przedsięwzięć.

W r. 1954 Bogdan Sadowski ukończył studia na Wydziale Lekarskim Akademii Medycznej w Warszawie, a następnie w latach 1954-1956 uzyskał specjalizację w dziedzinie neurologii. W 1962 r. uzyskał stopień doktora nauk medycznych w Akademii Medycznej w Warszawie, a w 1967 r. tytuł doktora habilitowanego nauk biologicznych w Instytucie Biologii Doświadczalnej im. Marcelego Nenckiego PAN w Warszawie. Prowadził prace badawcze, pracujac w latach 1957-1978 w Centrum Medycyny Doświadczalnej i Klinicznej PAN w Warszawie (obecnie Instytut Medycyny Doświadczalnej i Klinicznej im. M. Mossakowskiego PAN), w latach 1978-2002 kierował Zakładem Zachowania się Zwierzat w Instytucie Genetyki i Hodowli Zwierzat PAN w Jastrzębcu k. Warszawy, a następnie w latach 2003-2021 był wykładowca w Wyższej Szkole Inżynierii i Zdrowia w Warszawie.

Bogdan Sadowski prowadził prace badawcze również podczas zagranicznych staży naukowych. Na poczatku lat 60. ubiegłego stulecia odbył kilka krótkoterminowych sta- ży naukowych w Instytucie Fizjologii im. I. P. Pawłowa $\mathrm{w}$ Leningradzie (ZSRR). W latach 1960-1961 był też stypendysta rzadu włoskiego w Rzymie (Laboratorio di Chimica Terapeutica, Istituto Superiore di Sanitá), u Daniela Bovet, laureata Nagrody Nobla w 1957 r., znanego między innymi $z$ prac nad lekami antyhistaminowymi, kurara i zwiazkami o podobnym działaniu oraz badań nad wieloma innymi zagadnieniami dotyczacymi różnych aspektów farmakologii ośrodkowego układu nerwowego (OUN). Prof. Sadowski odwiedzał ten Instytut także kilkakrotnie w latach późniejszych. W latach 1965-1966, w ramach Postdoctoral Fellowship przyznanego $\mathrm{Mu}$ przez National Institutes of Health, przebywał w USA (Indiana University Bloomington) pracujac $\mathrm{w}$ zespole, którym kierował David B. Dill, wybitny specjalista w zakresie fizjologii sportu i wysiłku fizycznego. W latach 1974-1976 odbył kilka trzymiesięcznych staży (łacznie był to rok), pracujac jako pracownik naukowy w laboratorium badawczym firmy farmaceutycznej Janssen Pharmaceutica w Beerse, Belgia. W latach 1992-1993 był stypendysta Central and Eastern Europe Fogarty NIH Fellowship, pracując w ramach rocznego stypendium $w$ The University of California, Los Angeles (UCLA) w zespole, którym kierował John C. Liebeskind, pionier badań nad zwiazkami pomiędzy odczuwaniem bólu a aktywnością układu nerwowego i odpornościowego.

Bogdan Sadowski był autorem lub współautorem licznych publikacji naukowych $z$ zakresu fizjologii OUN i neurobiologicznych uwarunkowañ zachowań zwierzat. Wiele $\mathrm{z}$ nich ukazało się $\mathrm{w}$ znakomitych, renomowanych czasopismach o zasięgu międzynarodowym. Należy tu wymienić przede wszystkim powszechnie znane i cenione czasopisma publikujące wyniki badań podejmowanych $\mathrm{w}$ ramach szerokiego spektrum nauk przyrodniczych, a mianowicie Annals of the New York Academy of Sciences (MAREK i współaut. 1986b), Experientia (LIPKOWSKI i współaut. 1981) i Proceedings of the National Academy of Sciences (PNAS) (Mogil i współaut. 1996c). Prace autorstwa lub/i współautorstwa Bogdana Sadowskiego ukazywały się też w międzynarodowych cza- 
sopismach poświęconych fizjologii ogólnej, takich jak American Journal of Physiology (SZCZEPAŃSKA-SADOWSKA i współaut. 1979, 1982; KONARZEWSKI i współaut. 1997), Journal of Applied Physiology (ŁAPO i współaut. 2003c), Journal of Physiology-Paris (SADOWSKI i współaut. 1979, SzCZEPAŃSKA-SADOWSKA i współaut. 1981) i Pflügers Archiv European Journal of Physiology (SADOWSKI i SzCZEPAŃSKA-SADOWSKA 1974, ŁAPO i współaut. 2003a). Publikował także w czasopismach $z$ dziedziny nauk weterynaryjnych $i$ innych nauk o zwierzętach [Animal Reproduction Science (PRZEKOP i współaut. 1984), Journal of Veterinary Medicine Series A (PIEKARZEWSKA i współaut. 1999)]. Zamieszczał też liczne prace w czasopismach $z$ dziedziny neuronauk [Neuroscience Letters (KEST i współaut. 1998), Neurogastroenterology and Motility (WASILEWSKI i współaut. 1963)], w tym zwłaszcza relacjonujacych wyniki doświadczalnych badań mózgu [Brain Research (MogIL i współaut. 1993, 1994b; MAREK i współaut. 1993; PANOCKA i współaut. 1986a, b; KEST i współaut. 1999), Brain Sciences (NAWROCKA i współaut. 2021), Electroencephalography and Clinical Neurophysiology (SADOWSKI i LONGO 1962), Experimental Brain Research (WAUQUIER i współaut. 1975). Bardzo liczne prace Jego autorstwa lub/i wspó1autorstwa ukazały się też w czasopismach poświęconym badaniom fizjologicznych, neurobiologicznych, farmakologicznych, genetycznych i immunologicznych mechanizmów i korelat procesów i zjawisk behawioralnych: Behavior Genetics (MogIL i współaut. 1995b, SACHARCZUK i współaut. 2003a), Brain, Behavior, and Immunity (JUSZCZAK i współaut. 2008), Pharmacology, Biochemistry and Behavior (MAREK i współaut. 1983, 1986a; PANOCKA i współaut. 1987a; PANOCKA i SADOWSKI 1990b; SADOWSKI i PANOCKA 1993; LUTFY i współaut. 1996), oraz Physiology and Behavior (SADOWSKI 1972, 1974a; WAUQUIER i SADOWSKI 1978; PANOCKA i współaut. 1987b; SADOWSKI i KONARZEWSKI 1999; MOGIL i współaut. 1996b; BŁASZCZYK i współaut. 2000; ŁAPO i współaut. 2003b; SACHARCZUK i współaut. 2010a). Publikował też w czasopismach $z$ dziedziny biochemii i neurochemii [Archives Internationales de Physiologie et de Biochimie (SZCZEPAŃSKA-SADOWSKA i współaut. 1978; KONECKA i współaut. 1982, 1984), Neuropeptides (SZCZEPAŃSKA-SADOWSKA i współaut. 2020) i Peptides (PANOCKA i współaut. 2001] oraz farmakologii i neurofarmakologii [European Journal of Pharmacology (LUTFY i współaut. 1994a), General Pharmacology (KonECKA i współaut. 1981), Journal of Pharmacology and Experimental Therapeutics (MogIL i współaut. 1996a)], Neuropharmacology (POZNAŃSKI i współaut.
2017) i Proceedings of the Western Pharmacology Society (KEST i współaut. 1993)]. Jego prace ukazywały się też w czołowych czasopismach relacjonujacych wyniki badań nad bólem [Pain (MAREK i współaut. 1987, MOGIL i współaut. 1995c, SACHARCZUK i współaut. 2010b)] i nad biologicznym podłożem uzależnień [Addiction Biology (SACHARCZUK i współaut. 2014), Alcohol (SACHARCZUK i współaut. 2008)]. Publikował też w międzynarodowych czasopismach relacjonujacych wyniki badań nad środowiskowymi uwarunkowaniami mutagenezy i toksykologii [Journal of Environmental Pathology, Toxicology and Oncology (SACHARCZUK i współaut. 2012), Mutation Research - Genetic Toxicology and Environmental Mutagenesis (SACHARCZUK i współaut. 2003b)], a także w innych czasopismach biomedycznych [Journal of Human Kinetics (SADOWSKI 2008)].

Profesor Sadowski zamieszczał swoje prace również w czasopismach naukowych ukazujących się w Polsce, w tym zwłaszcza w czasopiśmie Acta Biologiae Experimentalis (SADOWSKI i TRACZYK 1963a, b; SADOWSKI 1965), które następnie przekształciło się $\mathrm{w}$ renomowane międzynarodowe czasopismo neurobiologiczne Acta Neurobiologiae Experimentalis (ANE) (SADOWSKI i DEMBIŃSKA 1973; SADOWSKI i współaut. 1976, 1984; SADOWSKI 1976b, 1980, 1988, 2001; PANOCKA i SADOWSKI 1990a; SACHARCZUK i współaut. 2009; BŁASZCZYK i współaut. 2010a, b). W stosunkowo wczesnym okresie swojej działalności naukowej (lata 1959-1977) publikował też często w czasopiśmie Acta Physiologica Polonica (SADOWSKI 1959, 1964, 1974b, 1976a, 1977; TRACZYK i współaut. 1960; TRACZYK i SADOWSKI 1962a, b, 1963b; BRZEZIŃSKA i współaut. 1963; SADOWSKI i KRUK 1964; KRUK i SADOWSKI 1966, 1972; TURLEJSKA-STELMASIAK i SADOWSKI 1971; TARCZYŃSKA i współaut. 1972; SzCZEPAŃSKA-SADOWSKA i SADOWSKI 1973). Prace Jego współautorstwa ukazywały się też w międzynarodowym czasopiśmie Animal Science Papers and Reports wydawanym przez Jego macierzysta placówkę naukowa, Instytut Genetyki i Hodowli Zwierzat PAN w Jastrzębcu (PIEKARZEWSKA i SADOWSKI 1995, FEDOROWICZ i współaut. 2007, SACHARCZUK i współaut. 2005b), w innych czasopismach wydawanych w Polsce, takich jak Bulletin de L'Academie Polonaise des Sciences Série des Sciences Biologiques (TRACZYK i SADOWSKI 1959, SADOWSKI 1960), Neurologia i Neurochirurgia Polska (SACHARCZUK i współaut. 2005a), Polish Journal of Pharmacology and Pharmacy (LiPKOwsKI i współaut. 1982) i Rozprawy Wydziału Nauk Medycznych (SADOWSKI 1962), a także w czasopismach wydawanych w innych państwach Europy Środkowej i Wschodniej: 
Acta Endocrinologica (Rumunia) (PRZEKOP i współaut. 1985), Acta Physiologica Hungarica (Węgry) (SADOWSKI i wspólaut. 1972) i Zhurnal Vysshei Nervnoi Deiatelnosti imeni I. P. Pavlova (ZSRR) (PAVLOVA i współaut. 1977),

Jak widać $z$ powyższego zestawienia, już same nazwy czasopism, w których ukazywały się publikacje autorstwa lub współautorstwa Bogdana Sadowskiego doskonale ilustruja zakres tematyki badań, w których uczestniczył. Szeroko znane sa zwłaszcza Jego prace poświęcone roli czynników genetycznych i układu opioidowego w sterowaniu odpowiedziami na stres u myszy, w tym zmianami wrażliwości na bodźce bólowe. Liczne publikacje dotycza zjawiska tzw. analgezji indukowanej przez stres u myszy, czyli zmniejszonej wrażliwości na bodźce bólowe, ujawniajacej się pod wpływem stresu (MAREK i współaut. 1983, 1986a, b, 1993; PANOCKA i współaut. 1986a, b, 1987a, b, 1991; SADOWSKI 1988; PANOCKA i SADOWSKI 1990a, b; MoGIL i współaut. 1993, 1995b, c, 1996b; SADOWSKI i PANOCKA 1993; LUTFY i współaut. 1994a; KONARZEWSKI i współaut. 1997; ŁAPO i współaut. 1999, 2003a, b; SADOWSKI i KonARZEWSKI 1999). Analgezję taka indukowano m.in. stosując drażnienie stóp myszy prądem elektrycznym (MAREK i współaut. 1983, 1986a, 1987; SADOWSKI 1988), ale stopniowo znacznie bardziej rozpowszechniła się metoda, w której stres indukujący analgezję wiązał się $z$ koniecznościa kilkuminutowego pływania w niezbyt ciepłej wodzie (PANOCKA i współaut. 1986a, b, 1987a, 1991; SADOWSKI 1988; PANOCKA i SADOWSKI 1990a, b, 1993; MAREK i współaut. 1993; MogIL i współaut. 1993, 1996b; SADOWSKI i PANOCKA 1993; LUTFY i współaut. 1994a; KONARZEWSKI i współaut. 1997; ŁAPO i współaut. 1999, 2003a, b). Bardzo ważnym elementem tych badań było wyselekcjonowanie dwóch linii myszy cechujacych się silna i słaba odpowiedzia analgetyczna na stres, czyli wysokoanalgetycznych myszy HA (ang. high analgesia) i niskoanalgetycznych myszy LA (ang. low analgesia). Dzięki temu powstał bardzo interesujący model doświadczalny, który był nastepnie stosowany w licznych badaniach porównawczych, majacych na celu rzucenie światła na szerokie spektrum zagadnień powiazanych $z$ ta tematyką. Lista prac publikujacych wyniki badań myszy HA i LA jest imponujacca, nawet jeśli wymienimy wyłacznie prace autorstwa lub współautorstwa Bogdana Sadowskiego (WASILEWSKI i współaut. 1963; PANOCKA i współaut. 1986a, 1986b, 1987a, 1987b, 1991, 2001; MAREK i współaut. 1987, 1993; SADOWSKI 1988, 1994, PANOCKA i SADOWSKI 1990a, b; KEST i współaut. 1993, 1998, 1999; MoGIL i współaut. 1993, 1994b, 1995b, c, 1996a, b; SADOWSKI i PANOCKA 1993; LUTFY i współaut. 1994a, b, 1996; KONARZEWSKI i współaut. 1997; SADOWSKI i KONARZEWSKI 1999; BŁASZCZYK i współaut. 2000, 2010a, b; SACHARCZUK i współaut. 2001, 2003a, b, 2005b, 2008, 2009, 2010a, b, 2012, 2014; ŁAPO i współaut. 2003a, 2003b, 2003c; FEDOROWICZ i współaut. 2007; JUSZCZAK i współaut. 2008; POZNAŃSKI i współaut. 2017; NAWROCKA i współaut. 2021). Należy jednak pamiętać, że prace te ukazywały się na przestrzeni prawie sześćdziesięciu lat.

Warto też podkreślić, że wiele $z$ nich relacjonowało wyniki badań aktywności roli układu opioidowego u myszy $z$ linii HA i LA. Badano w nich takie kwestie jak: wiązanie agonistów i antagonistów receptorów opioidowych w różnych strukturach mózgu (MoGIL i współaut. 1994b, KEST i współaut. 1999) oraz rolę układu opioidowego w różnych formach nocycepcji (percepcji bodźców bólowych) i antynocycepcji (MAREK i współaut. 1986a; SADOWSKI 1992; KEST i współaut. 1993, 1998; LUTFY i współaut. 1994b, 1996; MogIL i współaut. 1994a, b, 1996a; SADOWSKI 1994; SADOWSKI i KONARZEWSKI 1999; BŁASZCZYK i współaut. 2010b; SACHARCZUK i współaut. 2010b, 2012). U myszy z linii HA i LA badano w szczególności rolę układu opioidowego w zjawisku analgezji indukowanej przez drażnienie stóp prądem elektrycznym (MAREK i współaut. 1987, SADOWSKI 1988) i przez kilkuminutowe pływanie (PANOCKA i współaut. 1986a, 1987a, 1991, 2001; SADOWSKI 1988; PANOCKA i SADOWSKI 1990a, b; MAREK i współaut. 1993; MogIL i współaut. 1993, 1996b; SADOWSKI i PANOCKA 1993; LUTFY i współaut. 1994a; ŁAPO i współaut. 2003a, 2003c). Tematem kilku prac była też rola osi przysadkowo-nadnerczowej w regulacji stresu i analgezji indukowanej przez stres (MAREK i współaut. 1983; PANOCKA i współaut. 1987a, b). Badano też spożywanie etanolu przez myszy $z$ obu linii (SACHARCZUK i współaut. 2008, 2009, 2010a, 2014; POZNAŃSKI i współaut. 2017; NAWROCKA i współaut. 2021), w tym także rolę układu opioidowego w regulowaniu spożywania etanolu i zachowań indukowanych przez stres (a zwłaszcza zachowań o charakterze depresyjnym) (SACHARCZUK i współaut. 2009, 2014; POZNAŃSKI i współaut. 2017; NAWROCKA i współaut. 2021) oraz rolę układu opioidowego $\mathrm{w}$ regulowaniu pracy układu pokarmowego (WASILEWSKI i współaut. 1963). W innej serii doświadczeń badano u myszy HA i LA aktywność w otwartym polu i tzw. odruch wzdrygnieccia w odpowiedzi na bodziec akustyczny (ang. acoustic startle response, ASR) (BŁASZCZYK i współaut. 2000, 2010a, 2010b; PANOCKA i wspó1- 
aut. 2001; JUSZCZAK i współaut. 2008). Także i tym razem starano się rzucić światło na rolę układu opioidowego $\mathrm{w}$ sterowaniu tymi zachowaniami u myszy $z$ obu linii (BŁASzCZYK i współaut. 2000).

Przedmiotem kolejnych badań była rola układu opioidowego w procesach nowotworowych u myszy $z$ linii HA i LA (SACHARCZUK i współaut. 2012), czynniki wpływajace na genetyczna wrażliwość myszy na analgezje opioidowa (MogIL i współaut. 1995a, b, c), a także różne właściwości materiału genetycznego myszy $z$ linii HA i LA i ich wrażliwość na czynniki mutagenne (SACHARCZUK i współaut. 2003a, b, 2005b, 2010b; FEDOROWICZ i współaut. 2007).

Badano też u myszy HA i LA inne formy analgezji, takie jak: analgezja indukowana przez leworfanol, opioid znany $z$ silnego działania przeciwbólowego (MAREK i współaut. 1993), przez etanol (MogiLi współaut. 1993) oraz przez niska temperaturę stosowana w tzw. atmosferze Helox składajacej się $z$ helu i tlenu (SADOWSKI i KONARZEWSKI 1999; ŁAPO i współaut. 2003a, 2003c). Kilka ciekawych prac współautorstwa Bogdana Sadowskiego omawia też i porównuje różne metody badań nocycepcji u myszy (MAREK i współaut. 1992; MogIL i współaut. 1996a, b; LUTFY i współaut. 1996; SADOWSKI i KoNARZEWSKI 1999; ŁAPO i współaut. 2003a, b, c; BŁAsZCZYK i współaut. 2010b).

W przeciwieństwie do bardzo licznych publikacji omawiajacych wyniki badań $z$ użyciem myszy, zaledwie kilku prac współautorstwa Bogdana Sadowskiego dotyczyło badań z użyciem szczurów. Tematyka większości $z$ nich była podobna jak w przypadku doświadczeń z użyciem myszy. Analizowano w nich udział układu opioidowego w regulowaniu wrażliwości na ból u szczurów, u których indukowano analgezję stosujac drażnienie stóp prądem elektrycznym lub wymuszajac $u$ nich pływanie (PANOCKA i SADOWSKI 1990a). Badano też udział układu opioidowego w regulowaniu wrażliwości na ból u szczurów podczas samodrażnienia struktur należących do układu nagrody mózgu (SADOWSKI i współaut. 1984), a także wpływ samodrażnienia mózgu na aktywność nadnerczy (SADOWSKI i współaut. 1972). Odrębne, choć jednak pokrewne zagadnienie stanowił wpływ przewlekłego stresu na zawartość serotoniny $\mathrm{w}$ różnych strukturach mózgu i na cykl rujowy szczurzyc (PRZEKOP i współaut. 1984).

Znacznie częstszym obiektem badań doświadczalnych Bogdana Sadowskiego, zwłaszcza we wczesnym okresie Jego działalności naukowej, były króliki. Istotna rolę w tych badaniach odgrywało jadro ogoniaste (łac. nucleus caudatus), ważny element układu nagrody mózgu. Analizowano wpływ jednostronnej lezji (usunięcia) jądra ogoniastego oraz drażnienia tej struktury pradem elektrycznym na obronne odruchy warunkowe i różne inne wzorce ruchowe u królików (SADOWSKI 1959, 1970; SADOWSKI i TRACZYK 1963a, b). Opisano też wpływ drażnienia jądra ogoniastego na napięcie różnych mięśni (TRACZYK i SADOWSKI 1962a, c), a także wzrost poziomu acetylcholiny w jądrze ogoniastym, pojawiajacy się w następstwie drażnienia elektrycznego (TRACZYK i SADOWSKI 1959, 1962c, 1963a). SADOWSKI i LONGO (1962) przedstawili też wyniki badań, w których wytwarzano u królików odpowiedzi instrumentalne wzmacniane nagroda pokarmowa. Zwierzeta uczono pociagania pyszczkiem za pierścień w odpowiedzi na dźwięk brzęczyka, za co w nagrodę otrzymywały kawałki kapusty. W pracy tej zbadano też skutki podawania licznych zwiazków cholinergicznych, a także amfetaminy i LSD, stosujacc równolegle metody behawioralne oraz rejestrowanie aktywności elektrycznej różnych struktur mózgu. Z kolei TARCZYŃsKA i współaut. (1972) opisali metodę wytwarzania $u$ królików instrumentalnych odruchów warunkowych wzmacnianych spożywaniem wody. Badany był też wpływ elektrycznego drażnienia mózgu na tzw. odczyn limfopeniczny u królików, stanowiący oznakę pobudzenia układu przysadkowo-nadnerczowego, a więc stresu (SADOWSKI i KRUK 1964, KRUK i SADOWSKI 1966), a także wpływ elektrycznego drażnienia środkowego wzgórza na wzbudzenie i na stan podobny do snu (SADOWSKI 1965). TURLEJSKA-STELMASIAK i SADOWSKI (1971) opisali też metodę ogrzewania podwzgórza u królików za pomoca termody zasilanej prądem stałym, zaś KRUK i SADOWSKI (1972) zbadali wpływ ogrzewania podwzgórza na aktywność układów niespecyficznych mózgu królika. SADOWSKI (1964) prowadził też badania nad udziałem nieswoistych układów mózgu w ostrym zmęczeniu u królików. W nieco późniejszym okresie KONECKA i współaut. (1982, 1984) badali też u królików rolę układu opioidowego $\mathrm{w}$ regulacji temperatury ciała oraz pobierania pokarmu i wody stosując metodę infuzji agonistów receptorów opioidowych wprost do komór mózgu.

We wczesnej działalności naukowej Bogdana Sadowskiego dużą rolę odegrały też badania psów, które ogniskowały się przede wszystkim na kwestii identyfikacji elementów układu nagrody mózgu i poznawania ich właściwości. W tym celu zastosowano metodę samodrażnienia mózgu przez badane zwierzęta w połaczeniu ze szczegółowymi obserwacjami behawioralnymi i analiza ich zachowania (SADOWSKI 1972, 1974a; SADOWSKI i DEMBIŃSKA 1973; WAUQUIER i SADOWSKI 
1974, 1978; WAUQUIER i współaut. 1975). Już w pierwszym doświadczeniu $z$ tego cyklu badane psy mogły się całkowicie swobodnie poruszać, a drażnienie określonej struktury w mózgu odbywało się drogą radiową po naciśnięciu przez psa odpowiedniej dźwigni, do czego był wytrenowany. Uzyskano też potwierdzenie istnienia nagradzajacych efektów samodrażnienia mózgu dzięki stwierdzeniu, że technika ta może zostać zastosowana do wytwarzania instrumentalnych odruchów warunkowych (PAVLOVA i współaut. 1977, SADOWSKI 1980). Bardzo ciekawym wynikiem było odkrycie, że uaktywnianie układu nagrody przez samodrażnienie wywiera silny hamujacy wpływ na pobieranie przez psy pokarmu (SADOWSKI 1972, 1974a, 1976b; SADOWSKI i DEMBIŃSKA 1973).

SADOWSKI i współaut. (1979) zbadali też wpływ samodrażnienia specyficznych struktur mózgu przez psy na ich ciśnienie krwi i na tętno. Przeanalizowano również wpływ samodrażnienia specyficznych struktur mózgu i stężenia jonów wapnia w płynie mózgowo-rdzeniowym na temperaturę ciała psa (SADOWSKI i SzCZEPAŃSKA-SADOWSKA 1974, SADOWSKI 1976b), a także pobudzajace i hamujace efekty elektrycznego drażnienia określonych struktur mózgu na pragnienie i pobieranie wody (SzCZEPAŃSKA-SADOWSKA i współaut. 1978, 1979, 1981). Udokumentowano też rolę wazopresyny w pobudzaniu pragnienia (SZCZEPAŃSKA-SADOWSKA i SADOWSKI 1973; SZCZEPAŃSKA-SADOWSKA i współaut. 1980, 1982)

Koty nie były częstym obiektem badań Bogdana Sadowskiego i jego współpracowników. Jedynie trzy publikacje relacjonuja wyniki badań wpływu drażnienia elementów układu nagrody mózgu, w tym jądra ogoniastego, na aktywność elektryczną w obrębie różnych struktur mózgu kota (TRACZYK i SADOWSKI 1962b, 1964; SADOWSKI i współaut. 1976). Równie niewielka liczba publikacji omawia wyniki badań $z$ wykorzystaniem kawii domowych (dawna nazwa: świnka morska), w których udokumentowano wpływ stymulacji elektrycznej i podawania różnych peptydów (w tym także syntetycznych analogów peptydów opioidowych, enkefalin) na aktywność skurczowa izolowanego jelita (KoNECKA i współaut. 1981; LIPKOWSKI i współaut. 1981, 1982). Z kolei u owiec opisano wpływ przewlekłego stresu na różne aspekty stanu hormonalnego, stężenie beta-endorfin w różnych strukturach mózgu, a także na cykl rujowy (PRZEKOP i współaut. 1984, 1985). Natomiast u świń rasy Duroc przeanalizowano wpływ stresu wywołanego unieruchomieniem na poziom amin biogennych i ich metabolitów w różnych strukturach mózgu (PIEKARZEWSKA i SADOWSKI 1995, 1999).
Tylko jedna, i to bardzo wczesna publikacja Bogdana Sadowskiego i jego współpracowników poświęcona była fizjologii zwierzęcia nie będacego ssakiem. Udokumentowano w niej wpływ różnych zwiąków aktywnych na indukowana przez acetylcholinę aktywność skurczową mięśnia żaby (BRZEZIŃSKA i współaut. 1963).

W swych pracach doświadczalnych Bogdan Sadowski współpracował $z$ wieloma badaczami $z$ kraju i zza granicy, w tym przede wszystkim $z$ licznymi naukowcami $z \quad Z a-$ kładu Neurofizjologii Instytutu Biologii Doświadczalnej im. Marcelego Nenckiego PAN w Warszawie i z Zakładu Neurofarmakologii Molekularnej i Zakładu Biochemii Mózgu Instytutu Farmakologii PAN w Krakowie. Miał też w swoim dorobku publikacje, które powstały w wyniku współpracy naukowej $z$ Żona, prof. dr hab. Ewą Szczepańska-Sadowska (Ryc. 1). Publikacje te, dotyczace

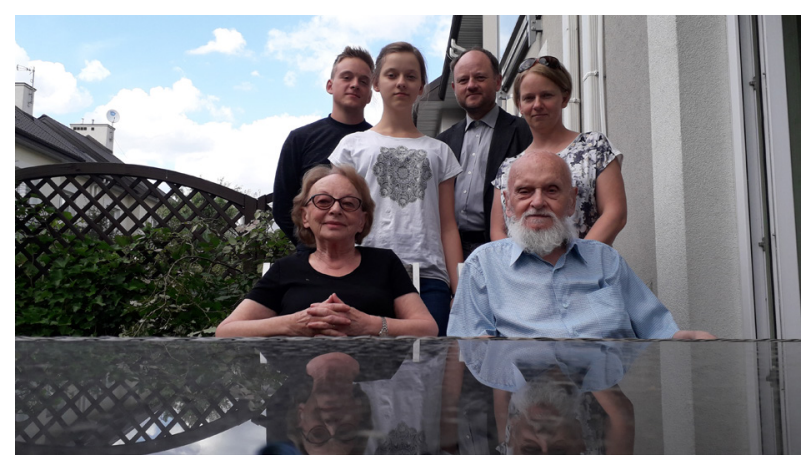

Ryc. 1. Zdjęcie rodzinne zrobione w ogródku przed domem 7 lipca 2019 r. W pierwszym rzędzie przy stole Bogdan Sadowski wraz $z$ żoną Ewą Szczepańską-Sadowska, za nimi synowa - Katarzyna Sadowska, wnuczka - Maria Sadowska, syn - Witold Sadowski i wnuk - Jan Sadowski.

osmoregulacji, termoregulacji i funkcji układu krażenia, ukazywały się przede wszystkim w latach 1973-1982 (SZCZEPAŃSKA-SADOWSKA i SADOWSKI 1973; SADOWSKI i SZCZEPAŃSKA-SADOWSKA 1974; SZCZEPAŃSKA-SADOWSKA i współaut. 1978, 1979, 1980, 1981, 1982). Ostatnia wspólna praca prof. Sadowskiego i prof. Szczepańskiej-Sadowskiej, poświęcona regulacji bólu przez neuropeptydy uczestniczące w regulacji funkcjonowania układu krążenia, ukazała się w 2020 r. (SzCZEPAŃSKA-SADOWSKA i współaut. 2020).

Trudno jest wybrać najważniejsze publikacje Profesora, ale niewątpliwie należy do nich artykuł przeglądowy poświęcony genetycznym uwarunkowaniom bólu i jego hamowania (MOGIL i współaut. 1996c), który ukazał się w jednym $z$ najbardziej prestiżowych międzynarodowych czasopism naukowych, Proceedings of the National Academy 
of Sciences (PNAS). Artykuł ten stanowił podsumowanie ówczesnego stanu wiedzy o genetyce zjawisk mających zwiazek z bólem, który został $\mathrm{w}$ istotnym stopniu poszerzony właśnie przez badania prowadzone w Instytucie Genetyki i Hodowli Zwierzat PAN w Jastrzębcu przez zespół prof. Sadowskiego. Zgodnie $z$ wyliczeniami Google Scholar, jest to też najczęściej cytowany artykuł współautorstwa prof. Sadowskiego.

Bogdan Sadowski był również autorem i współautorem wielu innych artykułów przeglądowych poświęconych zarówno kwestiom ogólnym, takim jak relacje pomiędzy stanami czynnościowymi niektórych ośrodków podkorowych mózgu i zachowaniem się zwierząt (TRACZYK i współaut. 1960), centralna kontrola głodu, sytości i homeostazy energetycznej (SADOWSKI 1976), organizacja funkcjonalna układu nagrody $i$ jego znaczeniem w procesach motywacji i wzmocnienia (SADOWSKI 1977), czy też plastyczność korowego układu ruchowego (SADOWSKI 2008), jak i innym ciekawym zagadnieniom interesujacym jednak przede wszystkim grona specjalistów, takim jak występowanie i funkcje białka laktoferyny w OUN (SACHARCZUK i współaut. 2005).

Do najważniejszych wczesnych osiągnięć badawczych Profesora można zaliczyć odkrycie, że uaktywnianie układu nagrody przez samodrażnienie wywiera silny hamujacy wpływ na pobieranie pokarmu przez psy (SADOWSKI 1974a). Warto tu też wspomnieć trzy prace opublikowane w prestiżowym czasopiśmie Pain, poświęcone genetycznym uwarunkowaniom analgetycznych odpowiedzi u myszy $z$ linii HA i LA na stres (MAREK i współaut. 1987, MogIL i współaut. 1995c, SACHARCZUK i współaut. 2010b). Ciekawa i wiele wnoszaca jest też praca ŁAPO i współaut. (2003a), dokumentująca interakcje pomiędzy mechanizmami uczestniczacymi w kontroli analgezji i termoregulacji u myszy oraz praca relacjonujaca wyniki porównawczych badań obszarów jąderkotwórczych chromosomów u myszy $z$ linii HA i LA (SACHARCZUK i współaut. 2003a). Nie można zapominać o ostatniej publikacji Profesora, która ukazała się kilka miesięcy temu w czasopiśmie Brain Sciences (NAWROcKA i współaut. 2021). Zamieszczono w niej wyniki badań nad wpływem wychowania krzyżowego (ang. cross-fostering) na spożycie etanolu i rozwój zachowań zbliżonych do depresyjnych u myszy $z$ linii HA i LA, które, jak to wykazały wcześniejsze doświadczenia, różnią się od siebie przede wszystkim aktywnościa układu opioidowego. Jak stwierdzili NAWROCKA i współaut. (2021), wychowanie przez matkę adopcyjna $z$ innej niż własna linii wywierało $u$ potomstwa silniejszy wpływ na rozwój zachowań depresyjnych niż na spożycie etanolu. Co ciekawe, spożywanie etanolu (i to zarówno przez matki adopcyjne, jak i przez biologicznych rodziców badanych myszy) prowadziło do modyfikacji wpływu naloksonu, antagonisty receptorów opioidowych, na rozwój zachowań depresyjnych u ich potomstwa (biologicznego lub adopcyjnego). Działo się tak jednak jedynie u myszy $z$ linii HA o silniejszej reakcji analgetycznej na stres.

Prof. Sadowski znany jest też wielu pokoleniom studentów, nauczycieli wyższych uczelni i innych osób zainteresowanych neurobiologia i naukami behawioralnymi przede wszystkim jako autor niezwykle cenionych książek i podręczników akademickich wydawanych w ciagu ostatniego półwiecza (1970-2021). W latach 70. ubiegłego stulecia ukazały się trzy ważne pozycje Jego autorstwa: Mózg i przystosowanie do środowiska (SADOWSKI 1970), Zarys biologii, anatomii $i$ fizjologii człowieka: wybrane zagadnienia dla studentów psychologii i pedagogiki (SADOWSKI 1971) i Fizjologiczne mechanizmy zachowania (SADOWSKI 1973). Kilkanaście lat później, częściowo na bazie tego ostatniego podręcznika, powstało znacznie szersze opracowanie napisane wspólnie $z$ profesorem Jerzym Andrzejem Chmurzyńskim, wówczas najwybitniejszym polskim ekspertem w dziedzinie etologii (p. GoDZIŃsKA 2019, 2020). Ten nowy, rozszerzony akademicki podręcznik nauk behawioralnych zatytułowany Biologiczne mechanizmy zachowania (SADOWSKI i CHMURZYŃSKI 1989), prędko stał się pozycją kultowa, gdyż autorom udało się połączyć w nim informacje dotyczace fizjologicznego i neurobiologicznego podłoża zachowań zwierzat badanych w warunkach laboratoryjnych, $z$ informacjami uzyskanymi dzięki stosowaniu podejścia etologicznego i dotyczacymi zachowań szerokiego spektrum grup zwierzęcych badanych zarówno w laboratorium, jak i w warunkach środowiska naturalnego. Podręcznik ten, nagrodzony Nagroda Naukowa im. M. Oczapowskiego VI Wydziału PAN, mimo upływu lat jest nadal bardzo chętnie czytany $\mathrm{i}$ to nie tylko przez studentów i nauczycieli akademickich, lecz również przez wiele innych osób pragnących pogłębić swoja wiedzę o zachowaniach zwierząt i o czynnikach, które je kształtują.

Po upływie kolejnych kilkunastu lat ukazała się też trzecia, znaczaco rozszerzona i zaktualizowana wersja pierwotnego podrecznika prof. Sadowskiego, zatytułowana tym razem Biologiczne mechanizmy zachowania sie ludzi i zwierzat (SADOWSKI 2005). Podręcznik ten miał następnie liczne wznowienia, a najnowsze jego wydanie, zmienione i rozszerzone, uwzględniajace aktualny stan i 


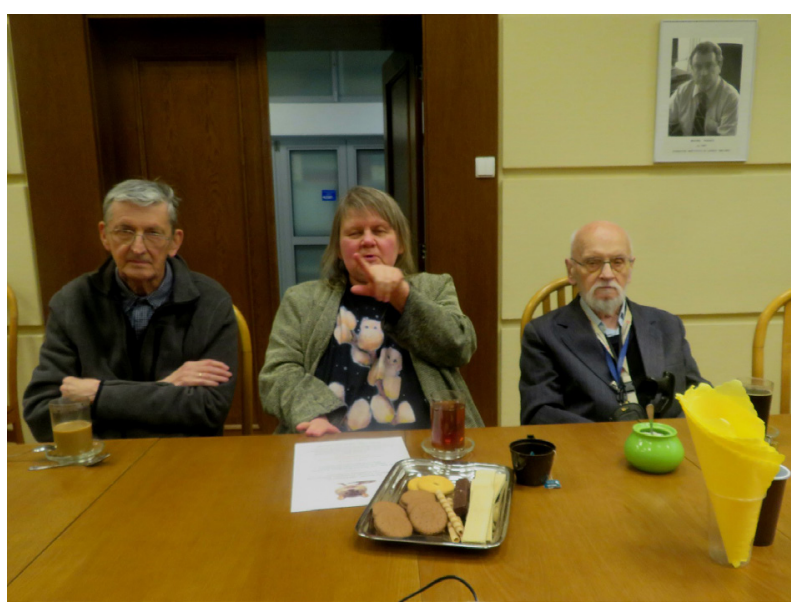

Ryc. 2. Dyskusja podczas 227. posiedzenia Polskiego Towarzystwa Etologicznego (21 lutego 2019 r.), podczas którego dr hab. Jan Manuel Rodriguez Parkitna (Zakład Neurofarmakologii Molekularnej Instytutu Farmakologii PAN w Krakowie) wygłosił wykład „Neuronalny mechanizm uczenia ze wzmocnieniem". Od lewej Wojciech Kostowski, Ewa Joanna Godzińska i Bogdan Sadowski.

osiagnięcia współczesnej neurobiologii, ukazało się w roku obecnym (SADOWSKI 2021).

Profesor Bogdan Sadowski znany był również ze swoich wykładów, jasnych, przykuwajacych uwage i nacechowanych wyjątkowa erudycją. Prowadził między innymi dla studentów Wydziału Psychologii Uniwersytetu Warszawskiego wykłady i seminaria $z$ przedmiotu „Biologiczne mechanizmy zachowania". Wykładał też fizjologię układu nerwowego człowieka oraz prowadził seminaria $z$ tego przedmiotu dla studentow polskich i obcojęzycznych Akademii Medycznej, a później Uniwersytetu Medycznego w Warszawie. W latach 2002-2021 prowadził też wykłady i seminaria $z$ fizjologii $i$ anatomii dla studentów polsko- i obcojęzycznych Wyższej Szkoły Inżynierii i Zdrowia w Warszawie. Wykłady prof. Sadowskiego $z$ fizjologii bólu zostały zarejestrowane $i$ sa dostępne na kanale YouTube pod adresami https://www.youtube.com/watch?v=vsDpigyO2g8, https: / /www. youtube.com/watch?v=qOgN3cl2dck oraz https://www.youtube.com/watch?v=nPteJX7164I.

Bardzo interesujace i pobudzajace do myślenia były też wystapienia prof. Sadowskiego podczas seminariów, sesji i konferencji naukowych (Ryc. 2). Niezapomniany, niezwykle inspirujący wykład mieliśmy przyjemność wysłuchać w dniu 23 marca 2019 r. podczas sesji naukowej „Etologia i nie tylko. Jubileuszowa sesja naukowa dla uczczenia 90-lecia urodzin prof. dr hab. Jerzego Andrzeja Chmurzyńskiego" (Ryc. 3). Wykład ten, zatytułowany „Medyczne i społeczne znaczenie neuronauk", doskonale ilustrował erudycję Prelegenta, a także Jego nieprzeciętne zdolności dokonywania ważkich syntez (Ryc. 4).

W związku $z$ działalnością dydaktyczną w Wyższej Szkole Inżynierii i Zdrowia w Warszawie (2002-2021) prof. Sadowski zainteresował się też tematyka relacji pomiędzy neurobiologia i kosmetologią. Niezwykle interesujacy wykład relacjonujacy te kwestie, zatytułowany "Neuroscience in beauty shop" ("Neuronauki w salonie kosmetycznym”) został przez Niego wygłoszony wspólnie $z$ uczennica i współpracowniczką, Marta Kolankowska-Trzcińska, podczas Seminarium Konorskiego w Instytucie Biologii Do-

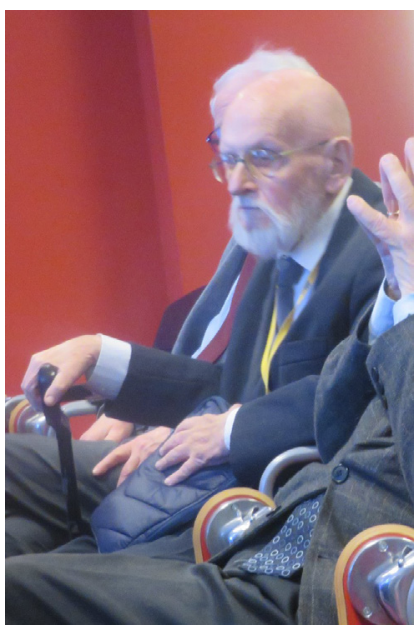

Ryc 3. Bogdan Sadowski podczas sesji naukowej „Etologia i nie tylko. Jubileuszowa sesja naukowa dla uczczenia 90-lecia urodzin prof. dr hab. Jerzego Andrzeja Chmurzyńskiego" (Warszawa, 23 marca 2019 r.).

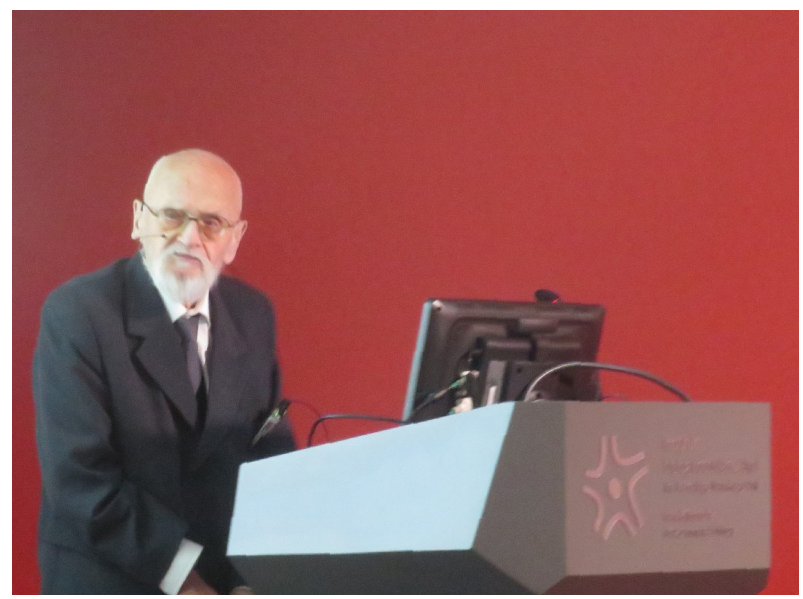

Ryc. 4. Bogdan Sadowski wygłaszajacy wykład „Medyczne i społeczne znaczenie neuronauk” podczas sesji naukowej „Etologia i nie tylko. Jubileuszowa sesja naukowa dla uczczenia 90-lecia urodzin prof. dr hab. Jerzego Andrzeja Chmurzyńskiego" (Warszawa, 23 marca 2019 r.). 


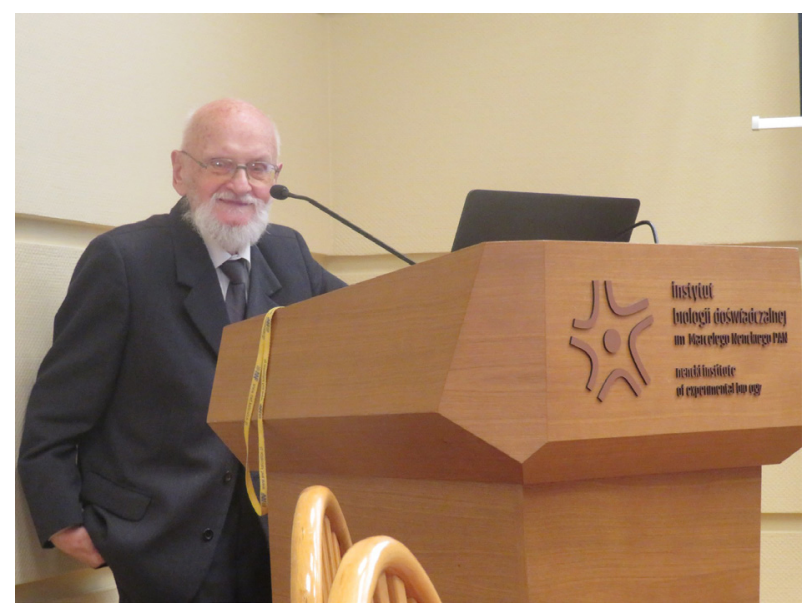

Ryc. 5. Bogdan Sadowski tuż przed rozpoczęciem wykładu „Neuroscience in beauty shop” („Neuronauki w salonie kosmetycznym") podczas Seminarium Konorskiego w Instytucie Biologii Doświadczalnej im. M. Nenckiego PAN (9 października 2019 r.).

świadczalnej im. M. Nenckiego PAN w dniu 9 października 2019 r (Ryc. 5). W wykładzie tym współprelegenci przedyskutowali $\mathrm{m}$. in. zagadnienia wpływu mimiki i wyrazu twarzy na przekaz i odbiór emocji oraz czynność obwodów układu limbicznego, a także neurobiologiczne mechanizmy medytacji buddyjskiej i jej świeckich odmian wykorzystujacych tzw. uważność (ang. mindfulness).

Bogdan Sadowski był Członkiem Honorowym Polskiego Towarzystwa Badań Układu Nerwowego (PTBUN), w którym działał od chwili jego założenia w r. 1991. Był też długoletnim aktywnym członkiem Polskiego Towarzystwa Fizjologicznego (PTF), a także Polskiego Towarzystwa Etologicznego (PTEtol.), w którym działał od 2006 r. Był też częstym gościem seminariów i sesji naukowych poswięconych neurobiologii i naukom behawioralnym, takich jak posiedzenia naukowe Polskiego Towarzystwa Etologicznego i seminaria Zakładu Neurofizjologii Instytutu Biologii Doświadczalnej im. M. Nenckiego PAN, które przekształciły się następnie w Seminaria Konorskiego. Jego wnikliwe komentarze wygłaszane podczas dyskusji przyczyniały się w ogromnym stopniu do zapewnienia tym spotkaniom wysokiego poziomu naukowego.

Ostatnie pożegnanie Profesora miało miejsce w piątek 5 marca 2021 r. na Starych Powazkach w Warszawie. Straciliśmy w Nim wybitnego uczonego, nauczyciela i mistrza wielu pokoleń neurobiologów i przedstawicieli nauk behawioralnych. Pozostana $z$ nami Jego książki, które na pewno jeszcze przez wiele lat będą dla nas stanowić źródło inspiracji i wiedzy o układzie nerwowym oraz jego roli w sterowaniu fizjologia i zachowaniami u zwierzat i ludzi.

\section{PODZIEKOWANIA}

Chciałybyśmy serdecznie podziękować Rodzinie Profesora Bogdana Sadowskiego, a w szczególności Jego Żonie, prof. dr hab. Ewie Szczepańskiej-Sadowskiej, za nieoceniona pomoc w uzyskaniu wielu cennych informacji dotyczacych zarówno kolei Jego życia, jak i prowadzonej przez Niego działalności badawczej i edukacyjnej. Jesteśmy też wdzięczne Rodzinie za przekazanie nam cennych zdjęć Profesora.

\section{LITERATURA}

BEASZCZYK J. W., TAJCHERT K., ŁAPO I., SADOWSKI B., 2000. Acoustic startle and open-field behavior in mice bred for magnitude of swim analgesia. Physiol. Behav. 70, 471-476.

BŁASZCZYK J. W., WERKA T., SADOWSKI B., 2010a. Acoustic startle and disruption of prepulse inhibition by dizocilpine in selectively bred mice. Acta Neurobiol. Exp. 70, 271-278.

BŁaszcZYK J. W., ŁaPO I. B., WERKA T., SADOWSKI B., 2010b. Differential startle magnitude in mice selected for high and low swim analgesia is not related to difference in nociception. Acta Neurobiol. Exp. 70, 398-405.

BRZEZIŃSKA Z., SADOWSKI B., TRACZYK W., 1963. Effect of some biologically active compounds on acetylcholine-induced contractions of the rectus abdominis muscle in frog. Acta Physiol. Pol. 14, 171-182.

FEDOROWICZ K., SACHARCZUK M., KonARZEWSKI M., ŁAPO I., KAWKA M., SADOWSKI B., ŚWIERGIEL A., JASZCZAK K., 2007. Divergent selection of mice for high and low swim stress-induced analgesia alters polymorphism at microsatellite loci. Anim. Sci. Pap. Rep. 25, 259-274.

GodZIŃSKA E. J., 2019. Prof. dr hab. Jerzy Andrzej Chmurzyński (11.03.1929 - 1.07.2019): entomolog, etolog, filozof, człowiek Renesansu. Wszechświat 120, 282-286.

GodZIŃSKA E. J., 2020. Jerzy Andrzej Chmurzyński (1929-2019): etolog, entomolog, myśliciel. Kosmos 69, 253-267.

JuSZCZAK G. R., BEASZCZYK J., SADOWSKI B., ŚLIWA A. T., WOLAK P., TYMOSIAK-ZIELIŃSKA A., LisowsKi P., ŚWIERGIEL A. H., 2008. Lipopolysaccharide does not affect acoustic startle reflex in mice. Brain Behav. Immun. 22, 74-79.

Kest B., Mogil J. S., Sternberg W. F., LiebeSKIND J. C., SADOWSKI B., 1993. Evidence for the up-regulation of kappa opiate mechanisms in mice selectively bred for high analgesia. P. W. Pharmacol. Soc. 36, 249-253.

Kest B., Mclemore G. L., SAdowski B., Mogil J. S., BELKNAP J. K., INTURRISI C. E., 1998. Acute morphine dependence in mice selectively-bred for high and low analgesia. Neurosci. Lett. 256, 120-122.

Kest B., JenaB S., Brodsky M., SAdowski B., BELKNAP J. K., MOGIL J. S., INTURRISI C. E., 1999. Mu and delta opioid receptor analgesia, binding density, and mRNA levels in mice selectively bred for high and low analgesia. Brain Res. 816, 381-389.

KoNARZEWSKI M., SADOWSKI B., JóŹWIK I., 1997. Metabolic correlates of selection for swim 
stress-induced analgesia in laboratory mice. Am. J. Physiol. 273, 337-343.

KONECKA A. M., SADOWSKI B., SROCZYŃSKA I., LIPKOWSKI A. W., MAJEWSKI T., DRABAREK S., 1981. Contracting activity of c-terminal fragments and a c-terminal hexapeptide analog of substance-p on non-stimulated and electrically stimulated isolated guinea-pig ileum. Gen. Pharmacol. 12, 119-121.

KonECKA A. M., SADOWSKI B., JASZCZAK J., PANOCKA I., SROCZYŃSKA I., MISICKA A., 1982. The effect of intracerebroventricular infusion of morphine, methionine-enkephalin and D-Ala2-enkephalinamide on body temperature of rabbits. Arch. Int. Physiol. Biochim. 90, 1-7.

KONECKA A. M., SADOWSKI B., JASZCZAK J., PANOCKA I., SROCZYŃSKA I. 1984. Suppression of food and water intake after intracerebroventricular infusion of morphine and naloxone in rabbits. Arch. Int. Physiol. Biochim. 92, 219-226.

KRUK B., SADOWSKI B., 1966. Wpływ drażnienia środkowego wzgórza na zachowanie się odczynu limfopenicznego u królików poddanych działaniu bodźca stresowego. Acta Physiol. Pol. 17, 445-464.

KRUK B., SADOWSKI B., 1972. Wpływ ogrzewania podwzgórza na aktywność układów niespecy ficznych mózgu u królików. Acta Physiol. Pol. 23, 427-437.

LIPKOWSKI A. W., DRABAREK S., MAJEWSKI T., KoNECKA A. M., SADOWSKI B., 1981. Effect of substitution of glycine by d-alanine or l-alanine on the activity of the c-terminal hexapeptide analog of substance-p on isolated guineapig ileum. Experientia 37, 499-500.

LIPKOWSKI A. W., KONECKA A. M., SADOWSKI B., 1982. Double enkephalins. Pol. J. Pharmacol. Phar. 34, 69-71.

LUTFY K., SADOWSKI, B., KWON I. S., WEBER, E., 1994a. Morphine analgesia and tolerance in mice selectively bred for divergent swim stress-induced analgesia. Eur. J. Pharmacol. 265, 171-174

LutFY K., SADOWSKI B., MAREK P., KwON I., KeANA J. F. W., WeBER E., 1994b. Analgesia-induced by morphine and ACEA-1011, a novel glycine/NMDA receptor antagonist in the formalin test in mice selectively bred for high and low swim-induced analgesia. FASEB J. 8, 629.

LUTFY K., SADOWSKI B., MAREK P., KWON I. S., KEANA J. F. W., WeBER E., 1996. Differential sensitivity of mice bred for stress-induced analgesia to morphine and ACEA-1011 in the formalin test. Pharmacol. Biochem. Behav. 54, 495-500.

ŁAPO I. B., SADOWSKI, B., ŚwIERGIEL A. H., KONARZEWSKI M., 1999. Swim stress-induced analgesia: Effect of hypothermia, or of fear of drowning? Abstr. Soc. Neurosci. 25, 1126.

ŁAPO I. B., KONARZEWSKI M., SADOWSKI B., $2003 a$. Analgesia induced by swim stress: interaction between analgesic and thermoregulatory mech anisms. Pflug. Arch. Eur. J. Phy. 446, 463469.

ŁAPO I. B., KONARZEWSKI M., SADOWSKI B., 2003b. Effect of cold acclimation and repeated swimming on opioid and nonopioid swim stress-induced analgesia in selectively bred mice. Physiol. Behav. 78, 345-350.

ŁAPO I. B., KONARZEWSKI M., SADOWSKI B., 2003c. Differential metabolic capacity of mice selected for magnitude of swim stress-induced analgesia. J. App. Physiol. 94, 677-684.

MAREK P., PANOCKA I., SADOWSKI B., 1983. Dexamethasone reverses adrenalectomy enhance- ment of footshock induced analgesia in mice. Pharmacol. Biochem. Behav. 18, 167-169.

MareK P., PANOCKA I., SADOWSKI B., 1986a. Activation of antinociceptive and pro-nociceptive mechanisms by front paw shock in spinal mice - involvement of humoral-factors. Pharmacol. Biochem. Behav. 24, 791-793.

MAREK P., PANOCKA I., SADOWSKI B., 1986b. Involvement of humoral-factors in the mechanism of stress-induced analgesia in mice. Ann. N. Y. Acad. Sci. 467, 361-370.

MAREK P., PANOCKA I., SADOWSKI B., 1987. Selec tive breeding of mice for high and low swim analgesia: differential effect on discrete forms of footshock analgesia. Pain 29, 393-398.

MAREK P., VACCARINO A. L., SADOWSKI B., LIEBESKIND J. C., 1992. A comparison of nociceptive responses using two methods of hot-plate measurements: Absolute temperature threshold versus reflex latency. Abstr. Soc. Neurosci. $18,1026$.

MareK P., Mogil J. S., BelKnaP J. K., SADOWSKI B., LIEBESKIND J. C., 1993. Levorphanol and swim stress-induced analgesia in selectively bred mice: evidence for genetic commonalities. Brain Res. 608, 353-357.

Mogil J. S., MAREK P., YiRMiYa R., Balian H., SADOWSKI B., TAYLOR A. N., LIEBESKIND J. C., 1993. Antagonism of the non-opioid component of ethanol-induced analgesia by the NMDA receptor antagonist $M K-801$. Brain Res. 602, 126-130.

Mogil J. S., SADOWski B., BelKNAP J. K., 1994a. Dissociation of the genetic mediation of anal gesic sensitivity to morphine by nociceptive assay. Abstr. Soc. Neurosci. 20, 310.

Mogil J. S., Marek P., Otoole L. A., Helms M. L., SADOWSKI B., LIEBESKIND J. C., BELKNAP J. K., $1994 \mathrm{~b}$. MU-opiate receptor-binding is up-regulated in mice selectively bred for high stress-induced analgesia. Brain Res. 653, 1622.

MogIL J. S., SAdowski B., BelKNaP J. K., 1995a. The role of the serotonin-1B receptor in genetic sensitivity to opiate analgesia in mice. Abstr. Soc. Neurosci. 21, 1415.

Mogil J. S., Flodman P., SPence M. A., STERnBERG W. F., KEST B., SADOWSKI B., LIEBESKIND J. C., BelKNAP J. K., 1995b. Oligogenic determination of morphine analgesic magnitude: a genetic analysis of selectively bred mouse lines. Behav. Genet. 25, 397-406.

Mogil J. S., Marek P., Flodman P., SPEnce M. A., Wendy A. S., Sternberg W. F., Kest B., SADOWSKI B., LIEBESKIND J. C., 1995c. One or two genetic loci mediate high opiate analgesia in selectively bred mice. Pain 60, 125-135.

Mogil J. S., Kest B., SADOWSKI B., BELKNAP J. K., 1996a. Differential genetic mediation of sensitivity to morphine in genetic models of opiate antinociception: Influence of nociceptive assay. J. Pharm. Exp. Ther. 276, 532-544.

Mogil J. S., STERnBerg W. F., BALIAN H., LIEBeSKIND J. C., SADOWSKI B., 1996b. Opioid and nonopioid swim stress-induced analgesia: A parametric analysis in mice. Physiol. Behav. 59,123

Mogil J. S., Sternberg W. F., Marek P., SADOWSKI B., BELKNAP J. K., LIEBESKIND J. C. 1996c. The genetics of pain and pain inhibition. PNAS, 3048-3055.

NAWROCKA A., POZNAŃSKI P., ŁAZARCZYK M., GORZAŁCZYŃSKI M., SKIBA D., WOLIŃSKA R, BUJALSKA-ZADROŻNY M., LUTFY K., SADOWSKI B., SACHARCZUK M., 2021. The influence of cross-fostering on alcohol consumption and de- 
pressive-like behaviors in HA and LA mice: the role of the endogenous opioid system. Brain Sci. 11, doi.org/10.3390/brainsci11050622.

PANOCKA I., SADOWSKI B., 1990a. Correlation between magnitude and opioid mediation of stress-induced analgesia: individual differences and the effect of selective breeding. Acta Neurobiol. Exp. 50, 535-547.

PANOCKA I., SADOWSKI B., 1990b. Potentiation of swim analgesia by D-amino acids in mice is genotype dependent. Pharmacol. Biochem. Behav. 37, 593-596.

PANOCKA I., MAREK P., SADOWSKI B., 1986a. Differentiation of neurochemical basis of stress-induced analgesia in mice by selective breeding. Brain Res. 397, 156-160.

PANOCKA I., MAREK P., SADOWSKI B., 1986b. Inheritance of stress-induced analgesia in mice - selective breeding study. Brain Res. 397, 152-155.

PANOCKA I., SAdOWsKi B., MareK P., 1987a. Adrenalectomy and dexamethasone differentially affect postswim antinociception in mice selectively bred for high and low stress-induced analgesia. Physiol. Behav. 40, 597-601.

PANOCKA I., SADOWSKI B., MAREK P., 1987b. Differentiation of pituitary-adrenocortical involvement in stress-induced analgesia in mice by selective breeding. Neuroscience 22, 141.

PANOCKA I., MAREK P., SADOWSKI B., 1991. Tolerance and cross-tolerance with morphine in mice selectively bred for high and low stressinduced analgesia. Pharmacol. Biochem. Behav. 40, 283-286.

PANOCKA I., MASSI M., ŁAPO I., ŚWIDERSKI T., KOWALCZYK M., SADOWSKI B., 2001. Antidepressant-type effect of the NK3 tachykinin receptor agonist aminosenktide in mouse lines differing in endogenous opioid system activity. Peptides 22, 1037-1042.

PaVlova O. G., Kosowski S., SAdowski B., 1977. Positive and differentiation instrumental selfstimulation conditioned reactions to sound in dogs. Zh. Vyssh. Nerv. Deyat. 27, 631-634.

PIEKARZEWSKA A., SADOWSKI B., 1995. Catecholamines and 5-hydroxytryptamine levels in the pig brain: The effect of acute restraint stress. Anim. Sci. Pap. Rep. 13, 283-289.

PiekaRZEwska A., SAdOWski B., Rosochacki S. J., 1999. Alterations of brain monoamine levels in pigs exposed to acute immobilization stress. J. Vet. Med. A 46, 197-207.

POZNAŃSKI P., LEŚNIAK A., KOROSTYŃSKI M., SZKLARCZYK K., LAZARCZYK M., RELIGA P., BUJALSKA-ZADROŻNY M., SADOWSKI B., SACHARCZUK M., 2017. Delta-opioid receptor antagonism leads to excessive ethanol consumption in mice with enhanced activity of the endogenous opioid system. Neuropharmacology 118, 90-101.

PRZEKOP F., WOLIŃSKA-WiTORT E., MATEUSIAK K., SADOWSKI B., DOMAŃSKI E., 1984. The effect of prolonged stress on the oestrous cycles and prolactin secretion in sheep. Anim. Reprod. Sci. 7, 333-342.

PRZEKOP F., STUPNICKA E., WOLIŃSKA-WiTORT E., MATEUSIAK K., SADOWSKI B., DOMAŃSKI E., 1985. Changes in circadian-rhythm and suppression of the plasma-cortisol level after prolonged stress in the sheep. Acta Endocrinol. $110,540-545$.

SACHARCZUK M., JASZCZAK K., SADOWSKI B., 2001. Cytogenetics characteristic of mice selectively bred for magnitude of stress analgesia. Ann. Genet.-Paris 44, 42.

SACHARCZUK M., JASZCZAK K., SADOWSKI B. 2003a. Chromosomal NOR activity in mice se- lected for high and low swim stres s-induced analgesia. Behav. Genet. 33, 435-440.

SACHARCZUK M., JASZCZAK K., SADOWSKI B., 2003b. Cytogenetic comparison of the sensitivity to mutagens in mice selected for high (HA) and low (LA) swim stress-induced analgesia. Mutat. Res.- Gen. Tox. En. 535, 95-102.

SACHARCZUK M., Zagulski T., SADOWSKI B., BARCIKOWSKA M. R., 2005a. Laktoferyna $w$ ośrodkowym układzie nerwowym. Neurol. Neurochir. Pol. 39, 482-489.

SACHARCZUK M., SADOWSKI B., PARADA R., ŚWIERGIEL A. H., JASZCZAK K., 2005b. DNA fingerprinting patterns in two lines of mice divergently selected for highand low swim stressinduced analgesia. Anim. Sci. Pap. Rep. 23, 129-138.

Sacharczuk M., JuszczaK G., Śllwa A. T., TYMOSIAK-ZIELINSKA A., LISOWSKI P., JASZCZAK K., Pluta R., Lipkowski A., SADOWSKI B., ŚWIERGIEL A. H., 2008. Differences in ethanol drinking between mice selected for high and low swim stress-induced analgesia. Alcohol 42, 487-492.

SACHARCZUK M., JuszczaK G., Świergiel A. H., JASZCZAK K., LIPKOWSKI A. W., SADOWSKI B., 2009. Alcohol reverses depressive and pronociceptive effects of chronic stress in mice with enhanced activity of the opioid system. Acta Neurobiol. Exp. 69, 459-468.

SACHARCZUK M., SADOWSKI B., JASZCZAK K., LIPKOWSKI A. W., ŚWIERGIEL A. H., 2010a. Opposite effects of alcohol in regulating stressinduced changes in body weight between the two mouse lines with enhanced or low opioid system activity. Physiol. Behav. 99, 627-631.

SACHARCZUK M., LEŚNIAK A., KOROSTYŃSKI M., PRZEWŁOCKI R., LIPKOWSKI A., JASZCZAK K., SADOWSKI B., 2010b. A polymorphism in exon 2 of the delta-opioid receptor affects nociception in response to specific agonists and antagonists in mice selectively bred for high and low analgesia. Pain 149, 506-513.

SACHARCZUK M., RAGAN A. R., SZYMAŃSKA H., LEŚNIAK A., SADOWSKI B., LIPKOWSKI A. W., 2012. Distinct susceptibility to inoculated melanoma and sensitivity to cancer pain in mouse lines with high and low sensitivity to stress. J. Environ. Pathol. Toxicol. Oncol. 31, 167-177.

SACHARCZUK M., LEŚNIAK A., LIPKOWSKI A. W., KoROSTYŃSKI M., PRZEWŁOCKI R., SADOWSKI B., 2014. Association between the A107V substitution in the delta-opioid receptors and ethanol drinking in mice selected for high and low analgesia. Addict. Biol. 10, 643-651.

SADOWSKI B., 1959. Defensive conditioned reflexes in rabbits after unilateral extirpation of caudate nucleus. Acta Physiol. Pol. 10, 1-10.

SADOWSKI B., 1960. Electric stimulation of the caudate nucleus as a stimulus for conditional defense reflex in rabbits. Bull. Acad. Polon. Sci. Ser. Sci. Biol. 8, 269-372.

SAdowski B., 1962. Badania nad funkcja jadra ogoniastego (nucleus caudatus). Rozpr. Wydz. Nauk Med. 7, 63-86.

SADOWSKI B., 1964. Badania nad udziałem nieswoistych układów mózgu $w$ ostrym zmęczeniu u królików. Acta Physiol. Pol. 15, 313-25.

SADOWSKI B., 1965. Some observations on sleeplike behavior and arousal produced by electric stimulation of the medial thalamus in rabbits. Acta Biol. Exp. 25, 219-232.

SADOWSKI B., 1970. Mózg i przystosowanie do środowiska. Seria Omega: biblioteka wiedzy powszechnej, Wiedza Powszechna, Warszawa. 
SADOWSKI B., 1971. Zarys biologii, anatomii $i$ fizjologii człowieka: wybrane zagadnienia dla studentów psychologii $i$ pedagogiki. PWN, Warszawa.

SADOWSKI B., 1972. Intracranial self-stimulation patterns in dogs. Physiol. Behav.8, 189-190.

SADOWSKI B., 1973. Fizjologiczne mechanizmy zachowania. PWN, Warszawa.

SADOWSKI B., 1974a. Negativism to food during self-stimulation in the anterior part of the basal forebrain in dogs. Physiol. Behav. 13, 645-651.

SADOWSKI B., 1974b. Osiagnięcia neurofizjologii polskiej $w$ trzydziestoleciu PRL. Acta Physiol. Pol. 25, 33-56.

SADOWSKI B., 1976a. Central control of hunger, satiety and energetic homeostasis. Acta Physiol. Pol. 27, 129-145.

SADOWSKI B., 1976b. Hyperthermia and inhibition of feeding produced by self-stimulation in septum and preoptic area in dogs. Acta Neurobiol. Exp. 36, 129-140.

SADOWSKI B., 1977. Układ nagrody: organizacja funkcjonalna $i$ znaczenie $w$ procesach motywacji $i$ wzmocnienia. Acta Physiol. Pol. 28, 5-36.

SADOWSKI B., 1980. External stimulus-control of self-stimulation behavior. Acta Neurobiol. Exp. 40, 239-250.

SADOWSKI B., 1988. Difference in escaping electric footshock by genetic mouse lines selectively bred for divergent levels of swim-induced analgesia. Acta Neurobiol. Exp. 48, 1-7.

SADOWSKI B., 1992. Genetic determination of opioid involvement in the mechanism of pain inhibition in mice. Acta Neurobiol. Exp. 52, 166.

SADOWSKI B., 1994. Selective breeding of mice for high and low stress-induced analgesia: Differentiation of opioid-mediated phenomena. Acta Neurobiol. Exp. 54, 277.

SADOWSKI B., 2001. Izabella Panocka (1955-2001) in memoriam. Acta Neurobiol. Exp. 61, III-IV.

SADOWSKI B., 2005. Biologiczne mechanizmy zachowania sie ludzi i zwierzat. PWN, Warszawa.

SAdowski B., 2008. Plasticity of the Cortical Motor System. J. Hum. Kinet. 20, 5-22.

SADOWSKI B., 2021. Biologiczne mechanizmy zachowania sie ludzi i zwierzat. Wyd. 3. PWN, Warszawa.

SAdOWSKI B., ChMurzyŃski J., 1989. Biologiczne mechanizmy zachowania. PWN, Warszawa.

SADOWSKI B., DEMBIŃSKA M., 1973. Some characteristics of self-stimulation behavior of dogs. Acta Neurobiol. Exp. 33, 757-769.

SADOWSKI B., KONARZEWSKI M., 1999. Analgesia in selectively bred mice exposed to cold in helium/oxygen atmosphere. Physiol. Behav. 66, 145-151.

SAdOWski B., KRUK B., 1964. Odczyn limfopeniczny u królików jako wyraz pobudzenia układu przysadkowo-nadnerczowego $w$ stanach czynnościowych wywołanych elektrycznym drażnieniem mózgu. Acta Physiol. Pol. 15, 477 493.

SADOWSKI B., LONGO V. G., 1962. Electroencephalographic and behavioural correlations of an instrumental reward conditioned response in rabbits - physiological and pharmacological study. Electroencephalogr. Clin. Neurophysiol. 14, 465-132.

SADOWSKI B., PANOCKA I., 1993. Cross-tolerance between morphine and swim analgesia in mice selectively bred for high and low stressinduced analgesia. Pharmacol. Biochem. Behav. $45,527-531$.
SADOWSKI B., SZCZEPAŃSKA-SADOWSKA E., 1974. The effect of calcium ions chelation and sodium ions excess in the cerebrospinal fluid on body temperature in conscious dogs. Pflug. Arch. Eur. J. Phy. 352, 61-68.

SADOWSKI B., TRACZYK W., 1963a. Conditioned reflexes established in unilaterally decorticated rabbits to caudate nucleus stimulation. Acta Biol. Exp. 23, 125-132.

SADOWSKI B., TRACZYK W., 1963b. Stimulation effects and bioelectrical activity of the caudate nucleus in unilaterally decorticated rabbits and cats. Acta Biol. Exp. 23, 101-113.

SAdOWSKi B., HARTMANN G., VERMES I., 1972. Effect of self-stimulation on adrenocortical activity in the rat. Acta Physiol. Hung. 42, 157162 .

SADOWSKI B., STUMPŁO D., RAJKOWSKI J., TARNECKI R., 1976. Modification of lateral hypothalamus (lh) single unit-activity by electric-stimulation of reward system in cats. Acta Neurobiol. Exp. 36, 723-724.

SADOWSKI B., WAUQUiER A., JAGENEAU A., JANSSEN P. A., 1979. Arterial blood pressure and heart rate changes during self-stimulation by dogs in the basal forebrain region, lateral preoptic area, hypothalamus, ventral midbrain and amygdala. J. Physiol.-Paris 75, 255-267.

SADOWSKI B., MAREK P., PANOCKA, I., 1984. Enhancement of performance for brain-stimulation reward after footshock in rats. Acta Neurobiol. Exp. 44, 51-59.

SZCZEPAŃSKA-SADOWSKA E., SADOWSKI B., 1973. Antidiuretic assay for vasopressin. Acta Physiol. Pol. 24, 479-483.

SZCZEPAŃSKA-SADOWSKA E., SOBOCIŃSKA J., SADOWSKI B., KosowsKI S., 1978. Osmotic thirst suppression elicited by electrical-stimulation of basal forebrain in dog. Arch. Int. Physiol. Biochim. 86, 169-173.

SZCZEPAŃSKA-SADOWSKA E., SobOcińSKA J., SADOWSKI B., KOsOWSKI, S., 1979. Inhibition of osmotic thirst by electric stimulation of the basal forebrain in dogs. Am. J. Physiol. 236, 117125.

SzCZEPAŃSKa-SADOWsKa E., Sobocińska J., SADOWSKI B., 1980. Evidence for stimulation of thirst by vasopresin. Eur. J. Clin. Invest. 10, 37.

SZCZEPAŃSKA-SADOWSKA E., SADOWSKI B., SOBOCIŃSKA J., 1981. Enhancement of osmotic thirst elicited by electric-stimulation of the limbic system in dogs. J. Physiol. 77, 671-674.

SZCZEPAŃSKA-SADOWSKA E., SOBOCIŃSKA J., SADOWSKI B., 1982. Central dipsogenic effect of vasopressin. Am. J. Physiol. 242, 372-379.

SZCZEPAŃSKA-SADOWSKA E., CUDNOCH-JĘDRZEJEWSKA A., SADOWSKI B., 2020. Differential role of specific cardiovascular neuropeptides in pain regulation, Relevance to cardiovascular diseases. Neuropeptides 81,102046. 102046. 10.1016/j.npep.2020.102046.

TARCZYŃSKA K., KARLIŃSKI A., SADOWSKI B., 1972. Metoda wytwarzania instrumentalnych odruchów warunkowych wzmacnianych woda $u$ królików. Acta Physiol. Pol. 23, 1087-1092.

TRACZYK W., SADOWSKI B. 1959. On increase of acetylcholine content in electrically stimulated caudate nucleus of a rabbit. Bull. Acad. Pol. Sci., S. Biol. 7, 331-335.

TRACZYK W., SADOWSKI B., 1962a. Alterations of the muscle tonus due to stimulation of the caudate nucleus in rabbits. Acta Physiol. Pol. 13, 609-620.

TRACZYK W., SADOWSKI B., 1962b. Electrical activity of the "cerveau isole" during caudate nucle- 
us stimulation and its modification by eserine and atropine. Acta Physiol. Pol. 13, 521-533.

TRACZYK W., SADOWSKI B., 1962c. Acetylcholine content in stimulated caudate nucleus in relation to muscle tonus and brain electrical activity. Abstracts of papers presented at XXII International Congress of Physiological Sciences, Leiden, 820.

TRACZYK W., SADOWSKI B., 1963a. Badania nad udziałem acetylocholiny $w$ czynności jadra ogoniastego. Streszczenia referatów i komunikatów IX Zjazdu Pol. Tow. Fizjologicznego, Toruń 1963, 284.

TRACZYK W., SADOWSKI B., 1963b. Badania nad rola acetylocholiny $w$ czynności jadra ogoniastego. Zawartość acetylocholiny $w$ jadrach ogoniastych a napięcie miessniowe. Acta Physiol. Pol. 14, 517-526.

TRACZYK W., SADOWSKI B., 1964. Electrical activity of the cerveau isole preparation and its relation to the acetylocholine content of the caudate nuclei. Electroen. Clin. Neuro. 17, 272280.

TraczyK W., SAdowski B., Pobudkowski A., Karcz S., BECK J., 1960. Stany czynnościowe nie- których ośrodków podkorowych a zachowanie się zwierzat. Acta Physiol. Pol. 11, 899-901.

TURLEJSKA-STELMASIAK E., SADOWSKI B., 1971. Metoda ogrzewania podwzgórza u królików za pomoca termody zasilanej pradem stałym. Acta Physiol. Pol. 22, 649-653.

WASILEWSKI A., LEŚNIAK A., BUJALSKA-ZADROŻNY M., SADOWSKi B., Fichna J., SACHARCZUK M., 1963. The effect of opioid agonists and antagonists on gastrointestinal motility in mice selected for high and low swim stress-induced analgesia. Neurogastroent. Motil. 28, 175185.

WAUQUIER A., SADOWSKI B., 1974. Brain self-stimulation in dogs - use of several stimulus-parameters and fixed-ratio schedules. J. Pharmacol. 5, 105.

WAUQUIER A., SADOWSKI B., 1978. Behavioral measurements of excitability changes in reward sites in dog - frequency-dependent effect. Physiol. Behav. 21, 165-168.

WAUQUiER A., MELIS W., SADOWSKI B., 1975. Brain self-stimulation in dogs - behavioral and vegetative correlates. Exp. Brain Res. 23, 214. 